\title{
STRATEGI PEMBELAJARAN MULTIPLE INTELLIGENCES DI TK/RA PONOROGO
}

\author{
Evi Muafiah
}

STAIN Ponorogo, Jawa Timur, Indonesia

\begin{abstract}
Early childhood is a basic time for children's further growth and development. They need conducive situation and conditions. One of the ways is by applying the Multiple Intelligences learning strategy that recognizes every child's different intelligences. This research shows that; (1) the application of Multiple Intelligences learning strategies in TK/RA Ponorogo, (2) the obstacles encountered in implementing the strategy, and (3) solutions used to overcome the obstacles they face. This study is a qualitative research. The sources of data were acquired from the TK/RA teachers through in-depth interviews, participant observation and documentation. While the analyses were performed by reduction, display, and data verification. The results of this study, are: (1) Multiple Intelligences Learning strategy implemented through the model of pure semi centers and groups. (2) The faced problems are the minimum number of teachers who are unbalanced and also less creative teachers. (3) The solution is to customize a theme that is being implemented through non learning model centers.
\end{abstract}

Keywords: learning strategy, multiple intelligence

\section{A. Pendahuluan}

Mencerdaskan kehidupan bangsa adalah cita-cita mulia bangsa Indonesia yang terkandung dalam pembukaan UUD 1945. Salah satu upaya untuk mewujudkannya adalah melalui penyelenggaraan pendidikan. Pendidikan di Indonesia merupakan tanggung jawab bersama antara keluarga, masyarakat dan negara yang disediakan mulai dari pendidikan di tingkat Pendidikan Anak Usia Dini (PAUD) hingga Perguruan Tinggi (PT). Namun sementara ini banyak kalangan yang masih beranggapan bahwa pendidikan bagi anak usia dini adalah pendidikan yang tidak begitu penting 
yang hanya menjadi jembatan untuk menuju pendidikan di sekolah dasar (Tirtaraharja dan La Sulo, 2005: 76).

Masa usia dini merupakan masa peletak dasar atau pondasi awal bagi pertumbuhan dan perkembangan selanjutnya. Maka sebenarnya wajar bila kita harus lebih memperhatikan pembelajaran bagi anak di usia tersebut. Diyakini oleh sebagian besar pakar pendidikan bahwa masa kanak-kanak yang bahagia merupakan dasar keberhasilan di masa mendatang (Yuliani dan Bambang Sujiono, 2010: 21). Untuk itu agar, pertumbuhan dan perkembangan tercapai secara optimal maka dibutuhkan situasi dan kondisi yang kondusif pada saat memberikan stimulasi dan upaya pendidikan yang sesuai dengan kebutuhan dan minat anak.

Para ahli pendidikan Indonesia banyak yang menyatakan bahwa strategi pembelajaran yang dirasa paling tepat diterapkan di tingkat PAUD adalah strategi pembelajaran yang menggunakan teori Multiple Intelligences atau kecerdasan majemuk dari Howard Gardner (Maryam Halim, 2007: viii). Teori ini menyatakan bahwa kecerdasan jamak adalah sebuah penilaian yang melihat secara deskriptif bagaimana individu menggunakan kecerdasannya untuk memecahkan masalah dan menghasilkan sesuatu. Sementara kecerdasan itu sendiri adalah kemampuan tertinggi yang dimiliki manusia. Gardner membuat kriteria dasar yang pasti untuk setiap kecerdasan agar dapat membedakan talenta atau bakat secara mudah sehingga dapat mengukur cakupan yang lebih luas tentang potensi manusia. Gardner memaparkan bahwa terdapat 8 aspek kecerdasan yaitu kecerdasan linguistik, kecerdasan logika matematika, kecerdasan visual spasial, kecerdasan kinestetik, kecerdasan musikal, kecerdasan interpersonal, kecerdasan intrapersonal dan kecerdasan naturalis.

Kecerdasan majemuk ini dapat saja dimiliki oleh setiap individu, hanya saja dalam taraf dan porsi yang berbeda. Kecerdasan ini tidak berdiri sendiri, terkadang bercampur dengan kecerdasan yang lainnya. Dengan kata lain, stimulasi terhadap satu kecerdasan akan menstimulasi kecerdasan yang lainnya. Sebagai contoh, untuk menyelesaikan konsep penjumlahan dalam matematika, seorang anak tidak hanya menggunakan kecerdasan logika matematika yang hanya harus berhadapan dengan deretan angka, namun lebih mudah baginya ketika menyelesaikan soal tersebut dengan kecerdasan linguistiknya dimana soal tersebut diberikan dalam bentuk cerita yang lebih mudah atau dimengerti (Yuliani dan Bambang Sujiono, 2010: 55). Seorang anak yang kesulitan memahami rumus-rumus fisika mungkin bisa terbantu dengan lantaran kecerdasan linguistik puisi yang dimilikinya (Munif Chotib, 
2013: 121).

Tidak semua orang atau guru di PAUD dapat menerapkan strategi pembelajaran menggunakan teori kecerdasan majemuk (Multiple Intelligences) dengan baik dan benar. Dengan berbagai alasan mereka mengatakan bahwa pembelajaran dengan menggunakan strategi tersebut sangat sulit dan butuh ketelatenan. Seorang guru dituntut untuk jeli dan cermat mengawasi perkembangan muridnya satu per satu dan selalu dituntut untuk menyuguhkan sesuatu yang baru bagi mereka.

Pendidikan anak usia dini memiliki karakteristikyang unikyaitu berupa aktivitas langsung dan berbagai sutuasi yang berkaitan dengan minat dan pengalaman. Mereka lebih cocok dengan pola pembelajaran konkrit dengan aktivitas motorik. Namun kenyataannya pendidikan anak usia dini menuai banyak dilema. Hingga saat ini banyak TK/RA yang menerapkan pendekatan penuh dengan hafalan membaca, menulis dan berhitung. Praktik yang sesuai dengan kebutuhan serta perkembangan anak belum seluruhnya diterapkan. Kecerdasan seorang anak biasanya hanya dinilai apakah dia sudah bisa membaca, menulis atau berhitung. Padahal menurut Gardner setiap individu mempunyai kecerdasan dan setiap individu itu cerdas (Musfiroh, 2008: 15). Banyak juga TK/RA yang sibuk dengan urusan memberikan les baca tulis bagi muridnya yang sudah akan masuk usia SD. Hal demikian memang sebuah dilema karena biasanya lembaga tersebut mendapatkan tekanan dari para wali murid bahwa setelah lulus TK/RA anak harus sudah dapat membaca, menulis dan berhitung. Orang tua mempunyai tuntutan demikian karena banyak juga SD/MI yang memang hanya menerima calon murid yang sudah dapat membaca, menulis dan berhitung. Hal tersebut diperparah lagi dengan strategi pembelajaran yang tidak sepenuhnya sesuai dengan perkembangan psikologis anak yang hanya siap belajar melalui permainan yang menyenangkan.

Penelitian ini mengungkapkan tentang (1) penerapan strategi pembelajaran Multiple Intelligences di TK/RA Ponorogo, (2) kendala yang dihadapi saat menerapkan strategi tersebut dan (3) solusi yang digunakan lembaga tersebut untuk mengatasi kendala yang mereka hadapi. Penelitian ini mengambil lokus di 3 lembaga TK/RA Muslimat NU Ponorogo yang merupakan binaan Yayasan Pendidikan Muslimat (YPM) NU Ponorogo. YPM NU Ponorogo membina lebih dari 180 TK/RA dan 50 Play Group. Salah satu usaha pembinaannya adalah mengadakan pelatihan pembelajaran menggunakan strategi Multiple Intelligences dalam model pembelajaran sentra di tahun 2009. Pelatihan tersebut dilanjutkan dengan 
pelatihan pembuatan kurikulum yang bermuatan Multiple Intelligences dan Ahlussunnah waljamaah pada tahun 2010. Dua kegiatan tersebut diikuti oleh seluruh TK/RA Muslimat NU Ponorogo. Lembaga TK/RA yang diteliti adalah TK Muslimat NU 1 Ponorogo, TK Muslimat NU 14 Banyudono Ponorogo dan RA Muslimat NU 24 Patihan Kidul Siman Ponorogo.

Penelitian ini merupakan penelitian berjenis field research yang menggunakan paradigma kualitatif. Sumber data primer adalah para guru di tiga TK/RA tersebut. Sedangkan sumber data sekunder adalah berupa data tertulis dan informasi dari beberapa informan selain dari yang disebutkan yang berada di lingkungan sekolah. Data diperoleh melalui wawancara mendalam, observasi partisipatif dan dokumentasi, serta dianalisis sedalam mungkin sebagaimana yang disampaikan Miles dan Huberman dengan dukungan trianggulasi data.

Kajian tentang Multiple Intelligences sudah banyak dilakukan, baik yang sudah berupa buku, penelitian lapangan maupun penelitian kepustakaan. Buku-buku yang membahas tentang teori Multiple Intelligences sebagian besar membahas bagaimana teori itu diaplikasikan dalam pembelajaran. Buku yang berjudul How to Multiply Your Child's Intelligence karya May Lwin sudah diterjemahkan oleh Cristine Sujana ke dalam bahasa Indonesia dengan judul Cara Mengembangkan Berbagai Komponen Kecerdasan (May Lwin: 2008). Buku ini membahas tentang pentingnya tujuh intelegensi atau kecerdasan menurut Howard Gardner untuk perkembangan anak secara keseluruhan. Buku ini juga dilengkapi dengan berbagai permainan dan kegiatan menarik yang dapat dilakukan dengan anak-anak untuk mengembangkan setiap kecerdasannya berikut figur tokoh terkenal yang berprestasi sesuai dengan masing-masing kecerdasan tersebut.

Buku dengan judul Bermain Kreatif Berbasis Kecerdasan Jamak karya Yuliani Nurani dan Bambang Sujiono membahas tentang kegiatan bermain anak usia dini yang kreatif dan berpijak pada kecerdasan majemuk (2010). Selain membahas tentang teori kecerdasan jamak dan model pembelajarannya, buku ini disertai dengan langkah pengembangan program kegiatan bermain di kelompok bermain, TK dan di Pos PAUD serta bagaimana cara mengevaluasi hasil pembelajaran tersebut. Di bagian akhir buku ini dicantumkan kiat sukses mengembangkan program kegiatan bermain bagi PAUD serta saran bagi para pemula untuk menerapkan bermain berdasarkan kecerdasan majemuk melalui gelaran sentra.

Buku yang ditulis berdasarkan rekaman kegiatan yang sudah pernah dilakukan adalah buku karya Munif Chatib yang berjudul Sekolahnya 
Manusia Sekolah Berbasis Multiple Intelligences di Indonesia (2013). Buku ini menceritakan keberhasilan pengarangnya dalam meningkatkan kualitas sekolah-sekolah yang dibinanya dengan menggunakan konsep MI yang juga dilengkapi dengan pengalaman menarik para murid yang merasa kesulitan dalam bidang pelajaran tertentu namun dengan strategi pembelajaran menggunakan konsep MI kesulitan tersebut tidak berarti lagi.

Penelitian yang berkaiatan dengan $M I$ telah dilakukan oleh Entin Fuji Rahayu dengan judul Manajemen Pembelajaran dalam Rangka Pengembangan Kecerdasan Majemuk Peserta Didik yang merupakan studi kasus di TK Kusuma Mulia Ngadiluwih Kediri. Penelitian ini memiliki tujuan utama untuk mendeskripsikan perencanaan, pelaksanaan, evaluasi, faktor pendukung, dan faktor penghambat manajemen pembelajaran dalam rangka pengembangan kecerdasan majemuk peserta didik di TK Kusuma Mulia Ngadiluwih Kediri. Hasil penelitian menunjukkan bahwa manajemen pembelajarannya meliputi tahapan perencanaan, pelaksanaan, evaluasi, serta memiliki faktor pendukung dan penghambat. Faktor penghambat antara lain: (a) jumlah ruangan kelas yang terbatas dan halaman tempat bermain yang kurang luas. Jumlah ruang kelas yang kurang diatasi dengan adanya shift mengajar atau sesi belajar. (b) Jumlah ruangan yang kurang memadai juga menyebabkan sekolah belum memiliki sentra atau area khusus layaknya TK yang sudah unggulan. Masalah ini disiasati dengan pembentukan kelas semi sentra dengan adanya kelompok-kelompok belajar serta pembagian tugas dalam satu kelas.

Penelitian yang lain adalah penelitian Tri Asmawulan dengan judul Pembelajaran di TK Al-Azhar Solo Baru ditinjau dari Sudut Pandang Multiple Intelligences (2009). Jika Entin meneliti TK di desa yang kategorinya masih sederhana, maka Tri meneliti sebuah TK yang masuk pada kategori sekolah unggulan modern. Penelitian ini bertujuan mendeskripsikan proses pembelajaran dan menganalisisnya menggunakan pendekatan Multiple Intelligences.

Jika dua penelitian sebelumnya meneliti penerapan Multiple Intelligences di TK, maka penelitian berikutnya ini adalah penelitian kepustakaan (library research) karya Handy Susanto dengan judul Penerapan Multiple Intelligences dalam Sistem Pembelajaran (2005) yang bertujuan (1) untuk mendeskripsikan dan menganalisis konsep multiple intelligences menurut Howard Gardner (2) untuk pengembangan multiple intelligences tersebut pada pembelajaran berbasis multiple intelligences bagi siswa usia pendidikan dasar. Hasil penelitian menunjukkan bahwa: (1) setiap individu 
pada dasarnya memiliki banyak kecerdasan yang harus dikembangkan sejak usia pendidikan dasar (minimal sejak usia pendidikan dasar). Minimal ada sembilan kecerdasan yang dimiliki manusia, yaitu kecerdasan linguistik, matematis-logis, ruang spasial, kinestetik badani, musikal, interpersonal, intrapersonal, naturalis dan eksistensial. (2) Pengembangan multiple intelligences pada metode pembelajaran pendidikan untuk siswa usia pendidikan dasar membutuhkan kreativitas seorang guru (pendidik), baik dalam mengatur, merencanakan, maupun menerapkan metode-metode tersebut.

Dari beberapa buku dan penelitian tersebut, belum ada yang meneliti tentang bagaimana konsep multiple intelligences diterapkan secara bersamasama oleh beberapa TK/RA yang berada di bawah suatu yayasan pendidikan. Penelitian ini memaparkan bagaimana lembaga-lembaga pendidikan tersebut menerapkan konsep multiple intelligences yang merupakan anjuran yang tertuang dalam kurikulum resmi yang telah ditetapkan oleh yayasan pendidikan yang menaunginya.

\section{B. Pembahasan}

\section{Konsep Multiple Intelligences dalam Pembelajaran di TK}

Taman kanak-kanak (TK) atau Raudlatul Athfal (RA) adalah sub sistem pendidikan nasional yang mempunyai peran penting dan strategis dalam meletakkan dasar pendidikan bagi masyarakat Indonesia. Jenjang pendidikan dini ini merupakan tahap awal proses pendidikan yang diselenggarakan secara terstruktur sebagai upaya pembentukan bangsa yang diharapkan mampu mandiri dan bersaing dengan bangsa lain di era mendatang. Menurut Undang-undang RI nomor 20 tahun 2003 tentang Sistem Pendidikan Nasional pasal 28 ayat 3, pendidikan TK/RA merupakan pendidikan anak usia dini pada jalur pendidikan formal yang bertujuan membantu peserta didik mengembangkan berbagai potensi fisik dan psikis yang meliputi nilai agama dan moral, sosial, emosional, kemandirian, kognitif, bahasa, motorik dan seni sebagai wahana untuk siap memasuki pendidikan dasar. Pendidikan di tingkat ini adalah pendidikan yang diterapkan dengan cara bermain. Hal ini dikarenakan bermain adalah sesuatu hal yang menyenangkan dan anak dalam usia TK/RA lebih tepat diajak belajar dalam suasana bermain.

Konsep kecerdasan majemuk dihadirkan untuk membantu mewujudkan cita-cita tersebut. Kecerdasan majemuk adalah istilah yang digunakan Howard Gardner untuk menunjukkan bahwa pada dasarnya

68 manusia itu memiliki banyak kecerdasan, tidak hanya sebatas IQ seperti 
yang dikenal selama ini. Menurut Gardner, setidaknya ada sembilan kecerdasan yang dimiliki oleh manusia yaitu kecerdasan linguistik, kecerdasan matematis-logis, kecerdasan ruang visual (spasial), kecerdasan kinestetik badani, kecerdasan musikal, kecerdasan antar pribadi, dan kecerdasan intra pribadi, kecerdasan naturalis, dan kecerdasan eksistensial (Wahyuni, 2007: 145). Kecerdasan merupakan kemampuan tertinggi manusia yang dapat digunakan untuk menghadapi permasalahan yang sedang dialaminya. Kecerdasan tersebut dimiliki sejak lahir dan secara terus menerus dapat dikembangkan melalui stimulasi yang dilakukan saat masa pertumbuhan dan perkembangan pada usia kanak-kanak. Kecerdasan majemuk merupakan penilaian yang melihat secara deskriptif bagaimana seseorang menggunakan kecerdasannya untuk memecahkan masalah dan menghasilkan sesuatu. Kecerdasan tersebut dimiliki oleh setiap individu dan hendaknya dikembangkan dengan maksimal sehingga anak yang dalam beberapa kecerdasan kurang menonjol dapat dibantu dan dibimbing untuk mengembangkan dan meningkatkan kecerdasan-kecerdasan tersebut.

Penelitian Howard Gardner tentang kecerdasan majemuk meruntuhkan beberapa asumsi tentang kecerdasan manusia, antara lain asumsi bahwa manusia bersifat satuan dan asumsi bahwa manusia dapat dijelaskan sebagai makhluk yang kecerdasannya dapat diukur dan tunggal. Sedangkan asumsi yang disampaikan Gardner berdasarkan penelitiannya adalah sebagai berikut:

a. Setiap manusia memiliki beberapa kecerdasan yang berbeda-beda dan menggunakan kecerdasan tersebut dengan cara yang sangat individual (antara satu orang dengan yang lainnya mempunyai cara yang berbeda dalam menggunakan kecerdasan-kecerdasan tersebut).

b. Setiap manusia mampu mengembangkan semua kecerdasan yang dimilikinya hingga mencapai tingkatan yang memadai.

c. Masing-masing kecerdasan bekerja sama dengan kecerdasan yang lain secara kompleks karena dalam setiap kecerdasan terdapat beberapa cara untuk menumbuhkan aspek kecerdasan yang lain.

Kalangan masyarakat terdidik dan para pakar pendidikan hingga saat ini lebih banyak mengenal teori kecerdasan rasional atau biasa disebut dengan IQ (intelligence quotient). Meskipun kritikan terhadap teori kecerdasan tersebut sudah banyak disampaikan oleh para ahli yang lain, namun masih saja dianggap sebagai satu-satunya alat ukur yang bisa menilai kecerdasan seseorang. Definisi kecerdasan sangat banyak macamnya. Hal ini dikarenakan mendefinisikannya tidak mudah dan bahkan berkembang 
searah dengan perkembangan ilmiah menyangkut studi yang berkaitan dengan otak manusia. Danah Zohar dan Ian Marshall memberikan definisi untuk tiga kecerdasan, yaitu IQ (intelligence quotient), EQ (emotional quotient) dan SQ (spiritual quotient) (Danah Zohar, 2007: 165). IQ didefinisikan sebagai kecerdasan yang digunakan untuk memecahkan masalah logika maupun strategis dan kecerdasan sering diukur dengan menggunakan testes IQ seseorang maka semakin cerdas orang tersebut. EQ didefinisikan sebagai kemampuan untuk mengenali perasaan diri sendiri dan perasaan orang lain yang memberikan rasa empati, cinta, motivasi, dan kemampuan untuk menanggapi kesedihan atau kegembiraan secara tepat, sedangkan SQ didefinisikan sebagai kecerdasan untuk menghadapi dan memecahkan persoalan makna dan nilai, yaitu kecerdasan untuk menempatkan perilaku dan hidup dalam konteks makna yang lebih luas dan kaya, serta kecerdasan untuk menilai bahwa tindakan atau jalan hidup seseorang lebih bermakna dibandingkan dengan yang lain.

Sementara itu, Alferd Binet dan Theodora Simon, sebagaimana dikutip oleh Saifudin Azwar mendefinisikan kecerdasan sebagai kemampuan untuk mengarahkan pikiran, mengubah arah tindakan bila tindakan tersebut telah dilakukan siswa, dan kemampuan untuk mengkritik diri sendiri atau melakukan autocriticism. Masih dikutip oleh Saifudin Azwar, V.A.C. Henmon mengatakan bahwa kecerdasan adalah kemampuan untuk memperoleh pengetahuan dan pengetahuan yang telah diperoleh. Pengertian ini, menurut Saifuddin Azwar, agar bersesuaian dengan definisi yang pernah diusulkan oleh Baldwin di tahun 1901 yang menyatakan kecerdasan sebagai daya atau kemampuan untuk memahami (Saifuddin Azwar, 1996: 5-6). Sedangkan Howard Gardner sebagaimana dikutip Agus Efendi menyatakan bahwa kecerdasan adalah kemampuan untuk memecahkan atau menciptakan sesuatu yang bernilai bagi budaya tertentu (Agus Effendi, 2005: 81).

Ketika mengantarkan bukunya yang kemudian menjadi terkenal, Frames of Mind, Howard Gardner menyatakan tidak percaya jika kecerdasan manusia itu hanya dapat diungkapkan dalam bentuk murni. Kemudian dia berhasil membuktikan bahwa kecerdasan seseorang itu tidak tunggal. Maka lahirlah teori kecerdasan majemuk atau Multiple Intelligences. Suatu kemampuan disebut kecerdasan atau inteligensi bila menunjukkan suatu kemahiran atau keterampilan seseorang untuk memecahkan persoalan dan kesulitan yang ditemukan dalam hidupnya. Selain itu, dapat pula menciptakan suatu produk baru dan bahkan dapat menciptakan persoalan berikutnya yang memungkinkan pengembangan pengetahuan baru. Dapat dikatakan 
bahwa dalam kemampuan itu ada unsur pengetahuan dan keterampilan (Paul Supomo, 2008: 21). Selanjutnya kemampuan tersebut berdampak pada kemampuan memecahakan persoalan yang dialami dalam kehidupan nyata. Namun, tidak berhenti di situ, pengetahuan juga dapat menciptakan persoalan-persoalan lebih lanjut berdasarkan persoalan yang dipecahkan untuk mengembangkan pengetahuan yang lebih maju dan canggih.

Teori kecerdasan majemuk atau Multiple Intelligences Howard Gardner berbeda dengan teori kecerdasan yang lain dalam beberapa hal, antara lain (Rina Buntaran: 2005):

a. Teori MI adalah teori fungsi kognitif yang menekankan bahwa setiap orang memiliki semua kapasitas kecerdasan yang bekerja dengan cara yang berbeda-beda, tetapi bersama-sama berfungsi secara khas dalam diri seseorang. Seseorang mungkin memiliki semua kecerdasan pada tingkat yang relatif tinggi, sementara orang lain mungkin hanya memiliki kecerdasan-kecerdasan itu dalam kondisi paling dasar.

b. Setiap individu dapat mengembangkan setiap kecerdasan sampai pada tingkat penguasaan yang memadai. Mereka sebenarnya mempunyai kapasitas untuk mengembangkan kecerdasan tersebut hingga tingkat tertinggi, asalkan memperoleh dukungan, pengayaan, dan pembelajaran yang tepat. Hal ini berarti bahwa seorang siswa yang memperoleh dukungan positif dari orang tua, fasilitas yang menunjang, bimbingan yang intensif memiliki peluang untuk mengembangkan kecerdasannya, seperti bermain musik, bercerita, melukis, dan menari.

c. Kecerdasan selalu berinteraksi satu dengan yang lain. Ketika bermain sepak bola, seseorang tidak semata-mata mengandalkan kecerdasan kinestetik (untuk menendang) tetapi juga memanfaatkan kecerdasan visual-spasial (untuk mengorientasikan diri dan mengantisipasi lintasan bola), bahkan kecerdasan interpersonal dan verbal linguistik ketika protes pada keputusan wasit.

d. Masing-masing kecerdasan mempunyai cara untuk berkembang hingga dikatakan menjadi cerdas. Seseorang tetap disebut cerdas linguistik karena kemahirannya bercerita, meskipun ia tidak lancar membaca. Demikian pula dengan orang yang tidak piawai di lapangan sepak bola, dapat dikategorikan cerdas dalam kinestetik apabila ia pandai menari dan luwes dalam gerak-gerik. Teori MI menekankan keberagaman cara orang menunjukkan bakat, baik dalam satu kecerdasan tertentu maupun antar kecerdasan. 
Kecerdasan majemuk tersebut adalah kecerdasan linguistik, kecerdasan logika matematika, kecerdasan fisik kinestetik, kecerdasan visual spasial, kecerdasan intrapersonal, kecerdasan interpersonal, kecerdasan musikal, kecerdasan naturalis dan kecerdasan spiritual (Stefanakis: 2002: 2). Keseluruhan kecerdasan tersebut dapat saja dimiliki setiap individu, namun tarafnya berbeda. Kecerdasan tersebut tidak berdiri sendiri. Antara satu kecerdasan dengan kecerdasan yang lainnya saling bercampur dan mendukung perkembangan masing-masing kecerdasan. Misalnya untuk menyelesaikan soal matematika seorang anak tidak saja menggunakan kecerdasan logika matematika yang harus berhadapan dengan deretan angka, namun lebih mudah baginya ketika menyelesaikan soal tersebut dengan kecerdasan linguistik melalui soal dalam bentuk cerita yang lebih mudah untuk dimengerti. Berikut diuraikan beberapa hal yang berhubungan dengan kecerdasan majemuk tersebut, yang urutan penyajiannya tidak menunjukkan bahwa satu kecerdasan lebih unggul dari kecerdasan yang lainnya.

a.. Kecerdasan Linguistik

Kecerdasan linguistik adalah kecerdasan mengolah kata serta mampu menggunakannya secara efektif melalui lisan ataupun tulisan. Orang yang mempunyai kecerdasan linguistik ini mampu berargumentasi, meyakinkan orang lain, menghibur atau berinteraksi secara efektif menggunakan kata-kata yang diucapkannya. Kecerdasan ini mempunyai empat ketrampilan, yaitu menyimak, berbicara, membaca dan menulis. Tujuan pengembangan kecerdasan ini adalah agar peserta didik mampu berkomunikasi dengan baik secara lisan dan tulisan, mampu berbahasa untuk meyakinkan orang lain, mampu mengingat dan menghafal informasi, mampu memberikan penjelasan, dan mampu membahas bahasa tersebut.

b.. Kecerdasan Logika Matematika

Kecerdasan logika matematika adalah kecerdasan dalam hal angka dan logika, yang meliputi keterampilan mengolah angka serta kemahiran menggunakan logika dan akal sehat untuk menganalisis masalah secara logis, menemukan atau menciptakan pola matematika dan menyelidiki sesuatu secara ilmiah. Materi program kurikulum yang dapat diterapkan untuk mengembangkan kecerdasan ini adalah bilangan, beberapa pola perhitungan, pengukuran, geometri, statistic, peluang, pemecahan masalah, logika, dan grafik.

72 c. Kecerdasan Fisik Kinestetik 
Kecerdasan ini adalah suatu kecerdasan untuk melakukan gerakan tubuh yang bagus seperti berlari, menari, dan terampil membuat berbagai karya seni. Materi program kurikulum yang dapat diterapkan untuk mengembangkan kecerdasan ini antara lain adalah berbagai aktifitas fisik, pantomim, menari, gerak tubuh, dan berbagai olah gerak.

c. Kecerdasan Visual Spasial

Kecerdasan ini erat kaitannya dengan kemampuan memvisualisasikan gambar dalam pikiran seseorang atau juga berpikir dalam bentuk visualisasi dan gambar untuk memecahkan suatu masalah dan menemukan jawaban. Materi program dalam kurikulum yang dapat digunakan untuk mengembangkan kecerdasan tersebut adalah aneka media satu, dua dan tiga dimensi, benda yang dapat dilihat dan diraba serta berbagai bentuk benda.

d. Kecerdasan Intrapersonal

Kecerdasan ini berupa kemampuan diri untuk berpikir secara reflektif, yaitu mengacu kepada kesadaran reflektif mengenai perasaan dan proses pemikiran diri sendiri. Sedangkan kegiatannya antara lain meditasi, mimpi, berdiam diri, mengikrarkan tujuan, refleksi, perenungan, membuat jurnal dan menilai diri. Materi program dalam kurikulum untuk mengembangkan kecerdasan ini antara lain: mengenal beberapa ekspresi perasaan, keyakinan diri, dan mengendalikan emosi.

e.. Kecerdasan Interpersonal

Kecerdasan interpersonal adalah berpikir melalui komunikasi dan interaksi dengan orang lain. Kegiatannya berupa berinteraksi dan saling berbagi dengan teman, menyayangi orang-orang yang dikenalnya, berbicara secara sopan, mengenal perasaan orang lain, bekerja sama serta mampu memimpin kelompok.

f. Kecerdasan Musikal

Kecerdasan musikal adalah kemampuan untuk menyimpan nada dalam diri seseorang untuk kemudian mengingatnya dan secara emosional terpengaruh untuk menikmati musik tersebut (May Lwin, 2008: 135). Seseorang dikatakan mempunyai kecerdasan musikal jika mampu mempersepsi, membedakan, mengubah serta mengekspresikan musik. Kecerdasan ini meliputi kepekaan pada irama, pola titi nada pada melodi, warna nada atau warna suara suatu lagu. Materi program dalam kurikulum untuk dapat mengembangkan kecerdasan ini adalah mendengarkan musik, melodi, instrumentalia, menyanyi sendiri atau bersama-sama sambil menari. 
g. Kecerdasan Natural

Kecerdasan naturalis adalah kemampuan untuk mengenali dan mengklasifikasikan aneka tumbuhan, binatang, makhluk hidup ataupun benda mati di lingkungan sekitar kita. Kecerdasan ini juga meliputi kepekaan pada fenomena alam seperti sungai, laut, gunung, hutan, bukit, danau, benda-benda tata surya, serta kehidupan di kota dan di desa. Materi kurikulum yang dapat digunakan untuk mengembangkan kecerdasan ini adalah melalui permainan sains sederhana, mengamati gejala alam serta hubungan antara benda hidup dan tak hidup yang ada di sekitar kita.

h. Kecerdasan Spiritual

Kecerdasan spiritual adalah kecerdasan yang mengakui bahwa segala sesuatu yang terjadi pada manusia adalah takdir Tuhan YME. Manusia harus menjalankan semua perintah Tuhan dan menjauhi laranganNya. Materi program kurikulum yang dapat dikembangkan antara lain adalah dengan mengajarkan berdoa setiap akan melakukan suatu pekerjaan, senandung pujian kepada Tuhan YME, membiasakan diri untuk berperilaku sebagaimana ajaran agama, misalnya mengucapkan salam bila bertemu, bersikap dermawan, sabar, menjaga kebersihan serta menanamkan rasa toleransi terhadap sesama makhluk Tuhan.

Setiap anak perlu mendapatkan kesempatan untuk mengembangkan seluruh aspek kecerdasannya. Anak mempunyai sejumlah kecerdasan dan gaya belajar yang berbeda dan dapat ditampilkan dalam berbagai cara yang berbeda serta sesuai dengan situasi dan kondisi. Tantangan bagi guru adalah menciptakan situasi dan kondisi yang sesuai untuk mengembangkan model pembelajaran berdasarkan tingkat kecerdasan majemuk yang dimiliki anak. Tujuan utama dalam mengetahui berbagai aspek yang terdapat dalam kecerdasan majemuk adalah agar guru dapat memperlakukan anak sesuai dengan cara dan gaya belajar masing-masing anak (Tim Pembinaan TK dan SD , 2010: 8).

\section{Pelaksanaan Pembelajaran Menggunakan Strategi Multiple Intelligences di TK/RA Ponorogo}

$\underset{3}{4}$ Penelitian ini dilakukan di tiga (3) TK/RA di Ponorogo, yaitu TK Muslimat NU 1 Ponorogo, TK Muslimat NU 14 Banyudono Ponorogo dan RA Muslimat NU 24 Patihan Kidul Siman Ponorogo. TK Muslimat NU 1 didirikan pada 1 Agustus 1943 dibawah naungan Departemen Pendidikan dan 74 Kebudayaan. Lembaga ini juga terdaftar di Departemen Agama pada 1 Juli 
1981. Lembaga ini berada di bawah Yayasan Pendidikan Muslimat NU Bina Bakti Wanita sejak tanggal 1 Agustus 2006 dengan nomor 01081943001. Sebagai lembaga pendidikan tertua, perkembangan TK Muslimat 1 dapat dikatakan cukup pesat dan menjadi sekolah pilihan utama serta mampu bersaing dengan lembaga pendidikan sejenisnya di Ponorogo. Sementara itu TK Muslimat NU 14 Banyudono terletak di jalan Kalimantan nomor 120 Ponorogo. Lembaga ini didirikan pada 6 Januari 1968 di bawah naungan Departemen Pendidikan dan Kebudayaan serta sudah terakreditasi B pada tanggal 17 Desember 2007. Lembaga ini berada di bawah Yayasan Pendidikan Muslimat NU Bina Bakti Wanita sejak tanggal 1 Agustus 2006 dengan nomor 06011968014. Meskipun letaknya agak di pinggir kota, namun keberadaan lembaga ini juga termasuk favorit. RA Muslimat NU Patihan Kidul Siman Ponorogo didirikan pada 1 April 1971. Saat itu masih menempati rumah penduduk yang satu pindah ke rumah penduduk yang lain, selain itu dengan sarana prasarana yang sangat sederhana RA Muslimat NU Patihan Kidul Siman Ponorogo berjalan terus dengan didasari semangat para guru, kepala sekolah, dengan didorong terus oleh komite serta masyarakat setempat.

Sebagai lembaga pendidikan yang berada di bawah Yayasan Pendidikan Muslimat NU Bina Bakti Wanita, ketiga TK/RA tersebut selalu mengikuti kegiatan yang diadakan oleh yayasan tersebut. Diantara kegiatan yang pernah diikuti adalah Pelatihan Implementasi Kurikulum Multiple Intelligences dan Metode Pembelajaran BCCT (Beyond Centers and Circle Times) yang diselenggarakan untuk Guru TK/RA Muslimat Kabupaten Ponorogo pada tahun 2009. Pelatihan tersebut dilanjutkan dengan Pelatihan Pengembangan Kurikulum Multiple Intelligences ala Muslimat NU pada tahun 2010.

\section{a. Kegiatan Pembukaan}

TK Muslimat 01 Ponorogo saat penelitian ini berlangsung sedang dalam tahap pembangunan gedung lantai 2 . Hal ini menyebabkan adanya penggabungan dua kelas menjadi satu kelas. Di beberapa tempat di luar kelas tampak beberapa jenis bahan bangunan sehingga keberadaannya agak mengganggu aktivitas belajar. Pembelajaran di lembaga pendidikan ini dimulai pada pukul 07.00 hingga 10.00, yang terbagi menjadi kegiatan pembukaan, inti dan penutup. Keseluruhan kelas terbagi menjadi kelas A dan Kelas B. untuk kelas A waktu pembelajaran lebih pendek, yaitu pulang jam 09.30. Istirahat untuk kelas A mulai pukul 08.45-09.00, sedangkan kelas B istirahat pada pukul 09.15-09.30. Kegiatan pembukaan dilakukan sekitar 45 menit yang diisi dengan kegiatan yang berbeda di setiap harinya. Semua 
kegiatan pembukaan dipandu oleh satu komando yang dilakukan oleh guru di kantor sekolah dan disebarluaskan melalui pengeras suara yang diletakkan di setiap kelas. Para peserta didik mengikuti kegiatan tersebut di kelas masing-masing yang didampingi oleh guru mereka.

Kegiatan pembukaan di hari Senin diawali dengan Upacara Bendera yang dilakukan bersama di halaman sekolah. Setelah selesai kemudian mereka memasuki kelas masing-masing dan dilanjutkan dengan pemeriksaan kuku dan rambut yang dikemas dengan nama kegiatan UKS (Usaha Kesehatan Sekolah). Kegiatan pembukaan diakhiri dengan hafalan hadits pendek. Kegiatan pembukaan di hari Selasa dan hari Kamis diawali dengan senam bersama yang diiringi dengan musik. Kemudian dilanjutkan dengan menghafalkan do'a sehari-hari di hari Selasa dan surat-surat pendek di hari Kamis. Kegiatan pembukaan di hari Rabu diawali dengan senam permainan tanpa musik dilanjutkan dengan praktik sholat subuh dan pelajaran bahasa Inggris. Hari Jum'at diawali dengan sholat Dhuha dan dilanjutkan bahasa Arab. Sedangkan hari Sabtu diawali dengan jalan-jalan dan kerja bakti.

Demikian juga yang terjadi di TK Muslimat NU 14 Banyudono. TK ini terbagi menjadi 4 kelas, yaitu A, B1, B2 dan B3. Dikarenakan ruang kelas yang tersedia hanya 3, maka kelas B1 dan B2 digabung menjadi satu. Lembaga ini terletak di jalan kecil, namun cukup ramai. Mempunyai halaman depan yang representatif untuk arena bermain anak-anak. Di halaman ini terdapat ayunan, prosotan, jungkat-jungkit dan titian bola dunia.

Pembelajaran dimulai pada pukul 07.30 dengan melakukan kegiatan bersama di luar kelas, tepatnya di halaman depan sekolah. Kegiatan tersebut diisi dengan senam bersama sambil bernyanyi, bermain dalam lingkaran besar serta berbaris. Beberapa saat kemudian secara berkelompok peserta didik masuk ke kelas masing-masing. Kemudian mereka diajak untuk melakukan aktivitas pembukaan di dalam ruang kelas yang diisi dengan berdo'a awal pelajaran, membaca do'a harian, membaca bacaan shalat atau al-Qur'an. Hari Senin dan hari Selasa kegiatannya adalah menghafalkan do'a keseharian beserta artinya, seperti do'a akan bepergian, do'a akan dan sesudah makan dan do'a naik kendaraan. Hari Rabu dan Kamis diajarkan niat berwudlu dan niat shalat lima waktu serta seluruh bacaan shalat. Hari Jum'at dan hari Sabtu menghafalkan surat-surat pendek dalam juz 30, seperti surat an-Naas hingga al-Fiil serta Ayat Kursi dan Asmaul Husna.

Sedangkan RA Muslimat NU 24 Patihan Kidul membagi peserta didiknya menjadi 7 rombongan belajar atau kelas, yaitu 1 kelas Playgroup terdiri dari 765 anak, kelas A1 sebanyak 24 anak, A2 sebanyak 24 anak, A3 sebanyak 20 
anak, B1 sebanyak 19 anak, B2 sebanyak 20 anak dan B3 sebanyak 20 anak. Sebagaimana dua TK sebelumnya, RA ini juga menerapkan model kelompok murni. Kegiatan pembukaan dilakukan sejak pukul 07.00 dan dilaksanakan di halaman depan sekolah yang diisi dengan senam, bernyanyi, berbaris, berdo'a sebelum melakukan kegiatan dan saling berjabatan tangan untuk kemudian masuk kelas masing-masing. Terkadang mereka juga diminta untuk memungut sampah yang ada di sekitar mereka dan memasukkannya ke dalam tempat sampah yang telah disediakan.

Setiap hari Jum'at mereka diajak untuk latihan wudhu dan shalat. Sedangkan di hari Sabtu mereka jalan-jalan di sekitar sekolah atau senam diiringi musik. Sekolah ini berada satu lokasi dengan madrasah ibtidaiyah. Kedua lembaga ini berada di dekat masjid. Halaman masjid, halaman RA dan halaman MI saling berdekatan atau bahkan dapat dikatakan menjadi satu. Sehingga halaman tersebut sangat luas dan membuat leluasa anak-anak RA bermain di sana. Sebagaimana umumnya lembaga TK/RA yang lain, TRA Muslimat 24 Patihan Kidul juga mempunyai beberapa mainan permanen yang diletakkan di halamannya, antara lain ayunan, prosotan, titian bola dunia dan jaring panjatan.

b. Kegiatan Inti

Dalam mengelola kegiatan pembelajaran yang menyenangkan, kreatif dan partisipatif, TK Muslimat 01 Ponorogo menerapkan model pembelajaran kelompok. Setiap anak dalam satu hari bermain dalam tiga kelompok yang di dalamnya terdapat tiga kegiatan yang meliputi sensori motor, bermain peran, dan pembangunan serta dilengkapi dengan satu sudut pengaman. Sudut pengaman diadakan sebagaitempatjikapara peserta didiksudah menyelesaikan tiga kegiatan lebih cepat dari waktu yang disediakan agar tidak mengganggu peserta didik yang lain yang masih belum selesai. Model pembelajaran tersebut dikenal dengan sebutan semi sentra. Namun tidak semua kelas menerapkan semi sentra, terutama kelas A. Hal tersebut dilakukan karena biasanya kelas A masih sulit diatur jika harus dibagi menjadi tiga kelompok. Biasanya kelas A diajar dengan sistem kelompok murni, yaitu seluruh siswa melakukan kegiatan yang sama dalam waktu yang sama.

Sekedar contoh, seorang guru di kelas A1 mengajarkan cara menggunting lalu menempelkan hasil guntingan tersebut. Seluruh peserta didik melakukan hal yang sama. Seorang guru di kelas A2 mengajarkan cara mewarnai sebuah gambar yang terdapat di buku cetak atau majalah anak-anak, maka seluruh peserta didik juga melakukan hal yang sama.

Sementara TK Muslimat NU 14 Banyudono membagi muridnya 
menjadi empat (4) rombongan belajar. Namun karena terbatasnya ruang kelas, maka mereka dibagi untuk menempati tiga (3) kelas. Ketiga kelas tersebut diselenggarakan dengan model kelompok murni, yaitu semua peserta didik melakukan kegiatan yang sama dalam waktu yang sama pula. Kelas B1 dan B2 yang digabung tersebut diajar oleh 2 guru dengan model kelompok murni.

Sekedar contoh, di kelas kelompok A yang merupakan siswa baru diajar mewarnai gambar rumah oleh guru dan seluruh siswa melakukan hal yang sama. Guru duduk mendekat ke meja anak-anak dan anak-anak duduk di kursi dengan meja yang semuanya menghadap kearah papan tulis. Suasananya seperti SD secara umum tapi siswanya TK. Demikian juga yang terjadi di dua kelas lainnya. Kelas B3 diajar oleh guru untuk menggambar wajah manusia dan seluruh siswa melakukan hal yang sama. Sedangkan kelas B1 dan B2 yang dicampur sedang diajarkan untuk menyebutkan anggota keluarga. Cara duduk mereka pun sama dengan kelas lainnya. Kelas kelompok A suasana lebih tenang karena mereka adalah murid baru, sementara kelas kelompok B lebih ramai karena murid lama dan bahkan ada yang tidak mau mengerjakan tugas yang diberikan oleh guru.

TK Muslimat NU 14 Banyudono ini menambah kegiatan siswa mereka dengan melakukan drum band di hari Senin dan Selasa untuk kelompok B, permainan Baca Tulis Hitung (Calistung) pada hari Rabu dan Kamis untuk kelompok B dan TPQ menggunakan buku IQRO' di hari Jum'at untuk semua kelompok.

Di RA Muslimat NU 24 Patihan Kidul, kegiatan inti dilaksanakan berdasarkan tema yang telah ditentukan dan pelaksanaannya sering dilakukan di dalam kelas. Kelas A1, A2, dan A3 terletak di lantai 1 gedung lama dan kelas B1 dan playgroup di lantai 1 gedung baru. Sedangkan kelas B2 dan B3 di lantai 2 gedung baru. Murid di kelas A1 semua duduk di atas kursi dengan bangku yang ditata rapi menghadap ke papan tulis di depan kelas. Murid di kelas A2 ada yang duduk di bawah dan ada yang di atas kursi. Kursi mereka diatur secara melingkar mengelilingi meja yang disatukan di tengah ruang kelas. Sementara kelompok A3 menempati kelas yang separoh ruangannya dipakai untuk meletakkan mainan mandi bola, sehingga kelas ini terlihat agak sempit. Semua anak duduk di kursi yang mengelilingi meja yang disatukan di tengah ruangan. Mereka tampak saling berdesakan. Kelompok playgroup menempati ruangan yang sekaligus juga untuk menyimpan alat bermain. Namun hal ini justru menyenangkan bagi mereka apalagi jumlah 78 mereka hanya 5 anak. 
Ruangan di sampingnya yang hanya disekat dengan papan adalah kelas yang digunakan untuk kelompok B1. Mereka menggunakan meja pendek dan duduk secara lesehan. Semua murid menghadap ke papan tulis. Mereka sedang menulis. Sebenarnya mereka dikelompokkan menjadi empat kelompok dan duduk berdasarkan kelompoknya dengan cara mengelilingi meja yang sudah ditentukan. Namun ternyata ada meja yang hanya ditempati satu murid saja. Ternyata murid tersebut adalah murid yang mereka cap sebagai anak yang usil sehingga mereka enggan sekelompok dengan anak tersebut. Kelompok B2 dan B3 menempati ruang kelas di lantai 2. Kedua ruangan itu hanya disekat dengan papan. Mereka semua duduk di kursi yang sudah ditata mengelilingi meja-meja yang disatukan di tengah ruangan sambil mengerjakan pekerjaan yang jenisnya sama, yaitu mewarnai. Kedua ruangan ini terasa lebih sempit karena mereka menggunakan kursi. Apalagi anak-anak kelompok B ini sebentar lagi sudah masuk SD. Postur tubuh mereka juga sudah relatif lebih besar sehingga kelas terasa sempit. Kursi dan meja yang digunakan juga bukan kursi untuk anak-anak. Berbeda dengan kelas B1 yang lesehan atau duduk di lantai. Kelas B1 terasa agak luas karena lesehan. Namun begitu model pembelajaran tetap dengan klasikal murni.

c. Kegiatan Penutup

Kegiatan akhir merupakan kegiatan penenangan yang biasanya juga dilaksanakan secara klasikal. Kegiatan yang diberikan antara lain membaca cerita dari buku, mendongeng, mendiskusikan kegiatan yang telah dilakukan, menginformasikan kegiatan esok hari, menyanyi, berdo'a dan diakhiri dengan duduk diam menunggu dipanggil guru untuk pulang. TK Muslimat NU 1 Ponorogo, TK Muslimat NU 14 Banyudono dan RA Muslimat NU 24 Patihan Kidul menerapkan kegiatan penutup tersebut secara bergantian. Saat menjelang pulang, ada anak yang kembali masuk kelas dan mengatakan bahwa dirinya minta PR. Kemudian Bu Guru menuliskan PR di buku anak tersebut dan memberikan buku tersebut kepada anak itu, sambil mengatakan bahwa beberapa anak selalu meminta PR dengan alasan yang disampaikan wali murid bahwa itu untuk latihan di rumah agar anak mau belajar dan tidak bermain saja saat di rumah.

d. Strategi Multiple Intelligences dalam Pembelajaran

Sebagaimana telah dipaparkan bahwa hampir semua kelas menerapkan model pembelajaran kelompok murni, meskipun ada beberapa yang menerapkan semi sentra. Semi sentra yaitu membagi kelompok menjadi tiga bagian kegiatan yaitu sensori motor, bermain peran dan pembangunan yang disertai dengan sudut pengaman. Ada beberapa kelas 
yang menerapkan semi sentra namun tidak banyak. Sentra adalah salah satu model pembelajaran yang dianggap paling cocok untuk menerapkan strategi Multiple Intelligences sebagai upaya untuk menstimulasi berbagai kecerdasan yang dimiliki anak, menanamkan kepribadian dan menumbuhkan kreatifitas sesuai dengan tahapan usia anak. Ketika para guru ditanya mengapa tidak menerapkan sentra, beberapa jawaban menyatakan bahwa untuk mengajar menggunakan sentra agak sulit dikarenakan butuh persiapan yang lebih matang, jumlah guru yang banyak, ruangan yang luas dan banyak serta pendanaan yang tidak sedikit. Terkadang sulitjuga mengendalikan anak-anak agar tidak menggunakan sentra tidak pada waktunya, sehingga penerapan sentra agak sedikit ribet. Diantara beberapa guru juga ada yang mengatakan bahwa sebenarnya sentra bukan satu-satunya model pembelajaran untuk menerapkan strategi Multiple Intelligences.

Ketika ditanya bagaimana kemudian mereka menerapkan strategi Multiple Intelligences di kelas yang tidak menggunakan model sentra, maka diantara jawabannya mengatakan bahwa mereka menyesuaikan dengan tema yang harus dilaksanakan saat itu. Mereka berusaha agar dapat menerapkan kecerdasan jamak meskipun sebenarnya mereka juga mengatakan bahwa Multiple Intelligences lebih tepat jika diterapkan menggunakan model sentra. Misalnya bodily kinesthetic diterapkan saat anak-anak diajak senam bersama di halaman setiap pagi saat kegiatan pembukaan, kecerdasan musikal dierapkan saat anak-anak diajak bernyanyi dan bertepuk, meskipun tidak selalu menggunakan alat musik. Interpersonal dierapkan saat anak bermain bersama atau saling berjabatan setiap akan pulang. Sedangkan intrapersonal diterapkan saat mendongeng untuk mereka. Beberapa guru mengakui bahwa mereka sangat jarang mendongeng dengan salah satu alasan karena para murid sudah menjelang masuk SD.

Diantara guru ada yang mengatakan bahwa sebenarnya Multiple Intelligences itu tepat apabila disampaikan dengan model sentra, karena anak-anak akan lebih leluasa mengembangkan kreatifitasnya, istilahnya lebih bebas bermain. Tapi terkadang ada wali murid yang protes atau kurang setuju jika anak-anak diajak bermain di luar kelas atau menurut mereka sekolah kok dolanan wae. Penerapan Multiple Intelligences biasanya diterapkan berdasarkan tema. Kecerdasan naturalis diterapkan dengan bermain pasir dan air yang dibawa ke dalam kelas. Tapi memang tidak semua bisa bermain, hanya perwakilan saja.

Ketika para guru ditanya mengenai kendala penerapan strategi Multiple Intelligences khususnya jika diterapkan melalui sentra, jawaban 
mereka diataranya mengatakan bahwa kendala terdapat pada ruangan yang kurang banyak dan kurang luas serta jumlah guru yang tidak seimbang dengan jumlah murid.

Sebagaimana telah dipaparkan sebelumnya bahwa terdapat beberapa kendala penerapan strategi Multiple Intelligences di TK/RA, terutama jika harus diterapkan melalui model sentra. Namun sebagian guru mengatakan bahwa Multiple Intelligences tetap bisa diterapkan meskipun tidak menggunakan sentra. Hal tersebut mereka perkuat sebagaimana jawaban berikut ketika secara umum ditanya bagaimana solusi mengatasi kendala penerapan Multiple Intelligences tidak melalui model sentra.

"Sentra memang bagus untuk perkembangan kreatifitas dan kemandirian anak-anak, tapi penerapan sentra sangat sulit bagi guru-guru kami. Namun kami tetap berusaha agar Multiple Intelligences bisa diterapkan pada anak-anak. Misalnya kecerdasan linguistic kami terapkan melalui bersyair, bernyanyi dan bercerita. Kecerdasan logika matematika melalui berhitung riil maupun bernyanyi yang ada hitungannya, seperti lagu Satusatu Aku Sayang Ibu atau Tek Kotek. Kecerdasan kinestetik melalui senam berirama atau senam yang ibu guru ciptakan sendiri. Untuk kecerdasan personalnya, anak saya ajari agar mampu memperkenalkan dirinya di depan kelas untuk intrapersonalnya, sedangkan untuk interpersonalnya, anakanak saya ajarkan bekerja dalam kelompok atau kerjasama menyelesaikan suatu tugas."

"Sebenarnya kami tidak melulu melakukan pembelajaran di dalam kelas, kadang-kadang anak-anak juga saya ajak jalanjalan di sekitar sekolah. Hanya saja memang mereka sangat sulit dikendalikan jika sudah diajak keluar kelas. Saya tidak mampu untuk mengendalikan mereka sendirian."

"Untuk bermain di sentra alam, misalnya, biasanya saya mengajak mereka bermain pasir dan air di halaman sekolah. Memang bak pasir yang kami miliki sudah tidak layak pakai."

"Sekolah kami mempunyai kegiatan ekstra drumband. Saya rasa ini cukup untuk menggembangkan kecerdasan musik mereka. Ya...meskipun yang boleh ikut drumband membawa 
alat adalah anak kelompok B. Anak kelompok A sekedar baris di belakangnya dan memainkan tongkat kecil mengikuti irama yang dimainkan pembawa alat".

"Membaca, menulis dan berhitung di tempat kami sebenarnya tidak hanya dilakukan dalam bentuk les saja. Tapi sehari-hari juga kami berikan dengan cara melalui lagu atau syair atau juga permainan. Kami sebenarnya juga paham kalau les Calistung itu tidak boleh diadakan di tingkat TK/RA.".

\section{Analisis Penerapan Strategi Multiple Intelligences di TK/RA Ponorogo}

Sebagaimana telah disebutkan pada bab sebelumnya bahwa beberapa ahli pendidikan banyak yang menyatakan bahwa strategi pembelajaran yang dirasa paling tepat diterapkan di tingkat PAUD adalah strategi pembelajaran yang menggunakan teori Multiple Intelligences atau kecerdasan majemuk dari Howard Gardner. Teori ini menyatakan bahwa kecerdasan jamak adalah sebuah penilaian yang melihat secara deskriptif bagaimana individu menggunakan kecerdasannya untuk memecahkan masalah dan menghasilkan sesuatu. Sementara kecerdasan itu sendiri adalah kemampuan tertinggi yang dimiliki manusia. Gardner membuat kriteria dasar yang pasti untuk setiap kecerdasan agar dapat membedakan talenta atau bakat secara mudah sehingga dapat mengukur cakupan yang lebih luas tentang potensi manusia. Gardner memaparkan bahwa terdapat 8 aspek kecerdasan yaitu kecerdasan linguistik, kecerdasan logika matematika, kecerdasan visual spasial, kecerdasan kinestetik, kecerdasan musical, kecerdasan interpersonal, kecerdasan intrapersonal dan kecerdasan naturalis. Dalam perkembangannya kemudian kecerdasan jamak ini ditambah dengan kecerdasan spiritual.

Penerapan kecerdasan jamak ini akan lebih tepat jika anak diberi kesempatan yang sangat luas untuk mengembangkan kecerdasan tersebut dengan menyediakan lingkungan yang sesuai dengan tahapan perkembangannya. Para pakar pendidikan kemudian menyatakan bahwa lingkungan tersebut disediakan dalam pembelajaran menggunakan model sentra. Sentra dapat menstimulasi anak untuk berkembang karena sentra dibuat semirip mungkin sebagaimana dunia nyata yang akan dijalani oleh anak kelak saat mereka dewasa.

Namun pembelajaran menggunakan model sentra ini dirasakan 82 sangat berat bagi para guru di TK/RA Ponorogo yang berada di bawah 
naungan Yayasan Pendidikan Muslaimat NU Ponorogo. Padahal yayasan tersebut telah menerbitkan Kurikulum berbasis Multiple Intelligences dan mengadakan pelatihan bagi guru TK/RA Ponorogo mengenai pembelajaran menggunakan model sentra. Pelatihan tersebut dilaksanakan sebanyak tiga tahap mengingat jumlah guru TK/RA yang berada di bawah naungan yayasan tersebut berjumlah lebih dari 500 orang. Hal ini dilakukan agar semua lembaga TK/RA Ponorogo dapat menerapkan strategi Multiple Intelligences dengan baik dan benar sehingga anak-anak mendapatkan pengalaman belajar dan bermain yang sesuai dengan tahapan perkembangan mereka.

Dikarenakan para guru tidak menerapkan model sentra dalam pembelajarannya, maka mereka melaksanakan strategi pembelajaran Multiple Intelligences sebisa mungkin dalam model pembelajaran yang mereka terapkan sehari-hari, yaitu model klasikal atau kelompok. TK Muslimat NU 1 Ponorogo lebih bijaksana mengatasi hal ini. Sebagian dari guru mereka melaksanakan pembelajaran model semi sentra, yaitu membagi anak dalam kelas tersebut menjadi 3 kelompok dan menyediakan 3 pengalaman yang berbeda dalam setiap kelompoknya. Masing-masing kelompok diberi kegiatan yang mengarah pada kemudahan menstimulasi kecerdasan jamak tersebut. Setiap anak dalam satu hari bermain dalam tiga kelompok yang di dalamnya terdapat tiga kegiatan yang meliputi sensori motor, bermain peran, dan pembangunan serta dilengkapi dengan satu sudut pengaman. Sudut pengaman diadakan sebagai tempat jika para peserta didik sudah menyelesaikan tiga kegiatan lebih cepat dari waktu yang disediakan agar tidak mengganggu peserta didik yang lain yang masih belum selesai. Lembaga ini juga mempunyai 2 kelas play group yang sudah menerapkan model sentra. Namun sayangnya kelas ini lokasinya agak jauh terpisah dari kelas TK nya, sehingga keberadaannya akan sulit untuk mempengaruhi agar guru di TK juga ikut menerapkan model sentra. Jika nantinya anak alumni play group ini melanjutkan di TK yang sama, maka mereka akan mengalami kemunduran dalam hal kesempatan mendapatkan pembelajaran yang lebih bijak, karena mereka akan bertemu dengan guru yang tidak menerapkan model sentra. Maka hendaknya lembaga ini segera merubah secara bersama-sama sistem pembelajarannya untuk menerapkan model sentra.

Sedangkan 2 TK/RA yang lainnya, yaitu TK Muslimat NU 14 Banyudono dan RA Muslimat NU 24 Patihan Kidul Siman masih menerapkan model klasikal murni. Dalam model pembelajaran ini, guru hanya memberikan satu pengalaman belajar yang akan diikuti oleh seluruh penghuni kelas tersebut. Sebenarnya kegiatan seperti model ini tidak memperkaya pengalaman anak, 
namun hal ini memang lebih mudah untuk dilakukan oleh guru, terutama jika dalam satu lembaga TK/RA rasio murid dan guru tidak seimbang. Perlu diketahui bahwa biaya pendidikan per bulan di TK/RA yang berada di bawah naungan YPM NU Ponorogo ini mayoritas sangat murah, yaitu berkisar antara 20.000 hingga 100.000. Namun sangat jarang yang di atas 50.000. Hal ini tentu saja berpengaruh terhadap gaji guru per bulan. Rata-rata gaji mereka antara 100.000 hingga 500.000. Namun mayoritas berada di bawah 500.000. Dengan demikian maka sangat berat jika harus menambah jumlah guru jika antara pemasukan dan pengeluaran dana lembaga tidak dapat memenuhi kebutuhan di tiap bulannya.

Penerapan Multiple Intelligences pada model klasikal murni yang mereka lakukan adalah dengan cara menyesuaikan dengan tema yang sedang dilaksanakan. Namun karena kegiatan yang dilakukan hanya satu macam, maka hal ini akan membuat anak tidak mempunyai pilihan lain dan harus mengikuti kegiatan tersebut. Jika anak mogok, maka bisa jadi hari itu dia tidak akan melakukan kegiatan apapun. Anak tersebut mungkin akan diam saja atau mengganggu temannya yang sedang melakukan kegiatan.

Pembelajaran model ini juga akan membentuk anak seakan-akan mereka sudah seperti gaya belajar anak SD. Suasana belajar yang diciptakan adalah semua murid duduk di atas bangku yang menghadap ke papan tulis. Jika anak sudah merasa tidak tahan duduk, maka biasanya mereka akan ramai atau bergerak kesana-kemari yang kemudian menyebabkan guru harus mengembalikan suasana yang diam. Padahal anak-anak tidak bisa untuk selalu duduk diam. Pada akhirnya guru akan setengah berteriak atau bahkan berteriak untuk menenangkan mereka. Suasana seperti ini sungguh tidak nyaman dan sebenarnya kurang baik untuk perkembangan belajar dan bermain bagi anak-anak.

Pembelajaran ala anak SD ini juga akan membentuk anak-anak belajar hal-hal yang belum waktunya. Pada salah satu TK/RA Ponorogo tersebut terdapat anak-anak yang sudah tidak mau diajak bermain saat belajar atau tidak mau diajak belajar sambil bermain. Mereka sudah punya anggapan bahwa mereka datang ke sekolah untuk belajar yaitu mereka harus membaca, menulis dan berhitung. Ketika pulang mereka selalu minta PR atau pekerjaan rumah yang juga berupa menulis dan berhitung. Hal tersebut sangat mendapat dukungan dari orang tua mereka masing-masing. Orang tua akan menegur guru baik secara langsung maupun tidak langsung jika guru masih menerapkan pembelajaran sambil melakukan permainan. Orang

84 tua beranggapan bahwa anaknya sudah tidak waktunya lagi belajar sambil 
bermain. Hal ini juga disebabkan setiap anak yang sudah lulus TK/RA harus sudah bisa membaca. Menulis dan berhitung. Jika tidak, maka mereka tidak akan dapat memasuki sekolah SD yang menjadi pilihan mereka. Hampir seluruh SD di Ponorogo sudah menerapkan aturan bahwa mereka akan menerima calon murid yang sudah bisa membaca, menulis dan berhitung.

Cara lain untuk menerapkan Multiple Intelligences adalah dengan mengajak anak-anak bermain di luar ruangan, misalnya pada saat tema alam semesta atau lingkunganku. Mereka diajak untuk bermain pasir dan air di luar kelas. Suasana ini sebenarnya sangat digemari anak-anak. Mereka dapat dengan leluasa mencampurkan air dengan pasir dan membentuknya menjadi sesuatu yang sesuai dengan keinginan mereka. Mereka juga dapat mengenal berbagai perubahan warna jika air yang diberi warna dasar kemudian dicampurkan antara satu dengan lainnya. Namun lagi-lagi hal ini akan menjadi sorotan orang tua wali murid, karena mereka menganggap bahwa ini hanyalah bermain belaka. Begitu juga misalnya mereka melakukan jalanjalan menyusuri daerah sekitar untuk mengenal alam sekitar. Bagi anak yang tinggal dekat dengan lingkungan tersebut, maka hal ini akan mengakibatkan mereka kurang tertarik dan akhirnya mengganggu temannya atau bahkan lari kesana-kemari mendahului barisan temannya. Hal yang demikian inilah yang menyebabkan akhirnya guru lebih memilih untuk selalu melakukan pembelajaran di kelas saja. Mereka menganggap bahwa belajar di kelas akan lebih aman dibandingkan di luar kelas. Padahal di sisi lain anak-anak akan merasa lebih senang jika belajar tidak selalu di dalam kelas. Mereka tidak tahan jika harus berlama-lama duduk diatas kursi. Anak dalam masa pertumbuhan akan selalu aktif dan tidak dapat duduk diam.

Multiple Intelligences lebih tepat diterapkan apabila menggunakan model pembelajaran sentra. Namun di lapangan terdapat beberapa kendala baik dari segi teknis maupun non teknis. Dari segi teknis akan selalu diperlukan adanya inovasi dan kreativitas dari para guru untuk menemukan berbagai kegiatan bermain yang akan menjadi pengalaman bagi anak-anak. Keanekaragaman kegiatan itu akan menjadi wahana bagi anak-anak menumbuh kembangkan kecerdasan yang dimilikinya. Guru harus meluangkan waktu lebih banyak untuk mempersiapkan segala sesuatunya dan harus siap sebelum anak-anak datang di sekolah. Persiapan tersebut dapat dilakukan setelah anak-anak pulang sekolah ataupun disaat pagi hari sebelum anak-anak datang. Hal inilah yang tidak begitu tampak pada 3 TK/RA yang menjadi lokus penelitian ini. Guru datang di kelas di pagi hari hampir bersamaan dengan datangnya anak-anak. Mereka tidak 
mempersiapkan apapun karena kebanyakan pembelajaran yang akan dilaksanakan menggunakan bantuan majalah sekolah sebagaimana Lembar Kerja Siswa (LKS) di tingkat SD dan tingkatan pendidikan di atasnya. Dalam majalah tersebut sudah ada berbagai ide kreatif yang sudah dikemas oleh perusahaan majalah, sehingga guru tinggal memakai dan mengajarkannya pada anak-anak dengan model klasikal atau kelompok murni.

Dari segi non teknis, maka strategi Multiple Intelligences dapat diterapkan dengan cara menambah jumlah guru atau menambahkan jumlah ruangan. Pertambahan tersebut akan mempermudah pengelolaan anakanak. Karena pada dasarnya rasio guru dan murid adalah 1:15-20. Namun sebenarnya dengan adanya guru dan ruangan yang terbatas bukan berarti strategi Multiple Intelligences tidak dapat dilaksanakan. Jika guru dapat memanfaatkan kreatifitas yang dimilikinya dan mau sedikit berkreasi dan meluangkan waktu untuk membuat persiapan kegiatan yang akan dilaksanakan pada pertemuan yang akan datang, maka strategi Multiple Intelligences akan bisa diterapkan dengan baik. Salah satu contoh adalah apa yang sudah dilakukan oleh beberapa guru di TK Muslimat NU 1 Ponorogo yang menerapkan model semi sentra.

Pepatah mengatakan bahwa "tak ada rotan akarpun jadi". Agaknya pepatah ini juga digunakan oleh guru-guru di TK/RA Ponorogo dalam rangka penerapan strategi Multiple Intelligences. Jika tidak bisa menerapkannya dalam model pembelajaran sentra dikarenakan beberapa kendala yang mereka hadapi, maka mereka harus dapat menerapkannya meskipun tidak dengan model sentra.

Beberapa hal yang mereka lakukan antara lain adalah menyesuaikan dengan tema yang sedang dilaksanakan saat itu. Jika temanya Diriku, maka misalnya masing-masing dari anak-anak diajak untuk menceritakan tentang dirinya dan keluarganya, makanan kesukaan, hobi dan hewan kesayangan. Jika temanya alam semesta, maka mereka bisa diajak ke luar ruangan untuk melihat lebih dekat alam sekitar mereka. Mereka juga bisa diajak mengunjungi rumah salah satu warga yang mempunyai usaha industri rumah tangga agar mereka tahu tentang hal-hal yang ada di sekitarnya.

Apa yang telah dilakukan TK/RA Ponorogo ini sebenarnya sudah lebih dari cukup dalam upayanya untuk menerapkan strategi Multiple Intelligences di dalam pembelajaran yang mereka lakukan. Hal ini terbukti dengan adanya standar kompetensi lulusan dan tingkat pencapaian perkembangan yang telah mereka buat sebagai acuan agar para lulusan lembaga tersebut menjadi $\sqrt{86}$ anak yang mempunyai talenta sebagaimana yang termuat di dalamnya. 
Standar tersebut juga telah disesuaikan dengan Kurikulum Muslimat NU yang telah diperkenalkan sejak tahun 2009. Namun mungkin standar kompetensi lulusan dan tingkat pencapaian perkembangan yang telah mereka buat tersebut belum diterapkan secara maksimal, sehingga nampak bahwa hal itu masih merupakan harapan yang belum nyata.

\section{Simpulan}

Penerapan strategi pembelajaran Multiple Intelligences di TK/RA Ponorogo dilaksanakan melalui model pembelajaran non sentra, yaitu semi sentra dan kelompok murni. Mereka tidak menerapkan model sentra dengan alasan antara lain kurangnya ruangan dan jumlah guru serta kurangnya ide kreatif untuk memperbanyak kegiatan pembelajaran.

Kendala yang dihadapi dalam menerapkan strategi pembelajaran Multiple Intelligences adalah ruangan yang kurang banyak dan kurang luas serta jumlah guru yang tidak seimbang dengan jumlah murid. Kekhawatiran terhadap pangsa pasar juga termasukyang menjadi kendala dalam penerapan strategi pembelajaran Multiple Intelligences tersebut.

Solusi yang digunakan TK/RA Ponorogo untuk mengatasi kendala penerapan strategi pembelajaran Multiple Intelligences adalah dengan menyesuaikan tema yang sedang dijalankan. Melalui tema itulah sebisa mungkin guru menstimulasi kecerdasan yang dimiliki oleh anak-anak, meskipun disisi lain ada beberapa ketidaksetujuan yang dirasakan oleh wali murid ketika melihat pembelajaran yang masih sarat dengan permainan. 


\section{DAFTAR PUSTAKA}

Agus Effendi. 2005. Revolusi Kecerdasan Abad 21, Bandung: Alfabeta.

Danah Zohar. 2007. SQ: Kecerdasan Spiritual, terj. Rahmani Astuti, Bandung: Mizan Pustaka.

Evangeline Harris Stefanakis. 2002. Multiple Intelligences and Portofolios: A Window Into The Learner's Mind, Porstmouth: Heinemann.

Imam Haromain dkk. 2009. Pedoman dan Implementasi Pengembangan KTSP $R A / B A / T A$, Surabaya: Departemen Agama Jawa Timur.

Mariyana, Nugraha dan Rahmawati, 2010. Pengelolaan Lingkungan Belajar, Jakarta: Kencana Perdana Media Group.

Maryam Halim dkk. 2007. Kurikulum PAUD Formal dan Non Formal Muslimat $N U$, Jakarta: Yayasan Pendidikan Muslimat NU Bina Bhakti Wanita Pusat.

May Lwin dkk. 2008. How to Multiply Your Child's Intelligence: Cara Mengembangkan Berbagai Komponen Kecerdasan, Terj. Christine Sujana, Jakarta: Indeks.

Munif Chatib. 2013. Sekolahnya Manusia; Sekolah Berbasis Multiple Intelligences di Indonesia, Bandung: Kaifa.

Paul Supamo. 2008. Teori Inteligensi Ganda dan Aplikasinya di Sekolah: Cara Menerapkan Teori Multiple Intelligences Howard Gardner, Yogyakarta: Kanisius.

Saifuddin Azwar. 1996. Pengantar Psikologi Intelligensi, Yogyakarta: Pustaka Pelajar.

Thomas Amstrong. 2005. Setiap Anak Cerdas: Panduan Membantu Anak Belajar dengan Memanfaatkan Multiple Intelligencenya, terj. Rina Buntaran, Jakarta: Gramedia Pustaka Utama.

Tim Pembinaan TK dan SD. 2010. Tingkat Pencapaian Perkembangan Anak Taman Kanak-kanak, Jakarta: Direktorat Pembinaan TK dan SD Dirjen Manajemen Pendidikan Dasar dan Menengah, Kementerian Pendidikan Nasioanl.

Tirtaraharja dan La Sulo. 2005. Pengantar Pendidikan, Jakarta: Rineka Cipta,

Yuliani Nurani dan Bambang Sujiono. 2010. Bermain Kreatif Berbasis Kecerdasan Jamak, Jakarta: Indeks. 